\title{
Prezentacje
}

\section{Świadomość mięśniowa. Wytwarzanie wiedzy w Arktyce}

Kirsten Hastrup

TEKSTY DRUGIE 2018, NR 1, S. 127-153

DOI: 10.18318/td.2018.1.8

$\mathbf{W}$ antropologii dyskusja o wytwarzaniu wiedzy jest zawsze na miejscu. A biorąc pod uwagę, że podstawę wiedzy antropologicznej stanowią indywidualnie prowadzone badania terenowe, to natura i prawomocność tej wiedzy i materiałów są stale przedmiotem badań'. Choć oczywiście są w antropologii różne punkty widzenia i różne podejścia teoretyczne, to „panuje zgoda co do tego, że wytwarzanie wiedzy to dynamiczny proces, będący bezpośrednim wynikiem nierozerwalnych związków łączących ze sobą umysły, ciała i środowisko"2.

1 M. Engelke The Objects of Evidence: Anthropological Approaches to the Production of Knowledge, "Journal of the Royal Anthropological Institute" 2008 (Special Issue); K. Hastrup Getting it Right: Knowledge and Evidence in Anthropology, "Anthropological Theory” 2004 No. 4, s. 455-472; T.H.J. Marchand The Objects of Evidence: Anthropological Approaches to the Production of Knowledge, ") Journal of the Royal Anthropological Institute" 2010 (Special Issue).

2 T.H.J. Marchand The Objects of Evidence, w: The Objects of Evidence: Anthropological Approaches to the Production of Knowledge, "Journal of the Royal Anthropological Institute" 2010 (Special Issue), s. 2.
Kirsten Hastrup profesor na Wydziale Antropologii Uniwersytetu w Kopenhadze. Jej zainteresowania badawcze obejmują teorię antropologiczną, epistemologię, antropologię historyczną, antropologię teatru, prawa człowieka, antropologię środowiska i antropologię topografii. Autorka książki A Passage to Anthropology. Between Experience and Theory i redaktorka tomu Anthropology and Nature. 
W niniejszym rozdziale chciałabym pokazać, jak taki proces może posłużyć jako podstawa wiedzy podlegającej uogólnieniu. Opieram się na niedawnych badaniach terenowych w Arktyce, których celem było zrozumienie, w jaki sposób myśliwi orientują się w swym coraz bardziej zmiennym otoczeniu.

Inspirację stanowiło pojęcie „świadomość mięśniowa” użyte przez $\mathrm{Ga}$ stona Bachelarda. Pamiętając, że jego rozważania nie były antropologią, lecz dotyczyły poezji, zacznijmy od zachwytu, jaki wzbudził w nim wiersz o drogach: „Jakże dynamiczną, piękną rzeczą jest droga! Jak precyzyjnie pozostają w świadomości naszych mięśni znajome drogi na wzgórzach!"3. Droga na wzgórzach, o której mowa w wierszu, odwołuje się do szczególnego odczucia ruchu i siły, potrzebnych, by się nią wspiąć; dzięki temu odwołaniu zaczyna się ona dla czytelnika łączyć z doświadczeniami skądinąd, a Bachelardowska poetyka przestrzeni łączy w jedno ludzi, miejsce i doświadczenie ciała. Nie chodzi tu po prostu o wiedzę ucieleśnioną - tak, jakby wiedza pochodziła spoza ciała; to proces działający w dwie strony. Poznawanie to proces, w którym ustanawiane są zarówno osoba, jak i wiedza ${ }^{4}$; jako ludzie stajemy się tym, kim jesteśmy przez nasz związek ze światem. Używam więc pojęcia świadomość mięśni, starając się uchwycić wzajemność relacji, w której określają się szlak i ten, kto go wytycza, a także by wskazać tryb poznania bezpośrednio związanego z doświadczeniem miejsca. W pewien sposób pobrzmiewa w nim stwierdzenie Merleau-Ponty'ego, że ciało ludzkie nie znajduje się po prostu w przestrzeni, lecz że tę przestrzeń zamieszkuje: „moje ciało ma swój świat albo rozumie swój świat i nie musi przechodzić przez „przedstawienia”, nie podporządkowuje się „funkcji symbolicznej” lub „obiektywizującej”. Etnograficzne badania terenowe oznaczają współzamieszkiwanie konkretnej przestrzeni - na bardzo różną skalę, w zależności od interesów poznawczych, które się podczas tego procesu pojawiają .

Moje przemyślenia akumulowały się podczas badań terenowych w rejonie Thule w północno-zachodniej Grenlandii (Avanersuaq) w ciągu ostatnich

G. Bachelard The Poetics of Space, trans. M. Jolas, Beacon, Boston 1964, S. 11.

4 T. Ingold Footprints Through the Weatherworld: Walking, Breathing, Knowing, w: The Objects of Evidence: Anthropological Approaches to the Production of Knowledge, ed. by T.H.J. Marchand, ")ournal of the Royal Anthropological Institute" 2010, S. 134.

5 M. Merleau-Ponty Fenomenologia percepcji, przeł. M. Kowalska, J. Migasiński, Fundacja Aletheia, Warszawa 2001, s. 160.

6 K. Hastrup Scales of Attention in the Field: Global Connections and Local Concerns in the Arctic, "Ethnography" 2013 No. 14 (2), s. 145-164. 
sześciu lat. Podobnie jak inne miejsca w Arktyce, Avanesuaq podlega dość dramatycznym zmianom w związku z globalnym ociepleniem, które poważnie zagraża od dawna praktykowanemu tam łowiectwu? ${ }^{7}$. Mieszkańcy nie tylko są świetnie zorientowani w problematyce zmiany klimatu oraz związanych z nią kwestiach globalnych, ale interesują się też zmianami politycznymi we współczesnej Grenlandii, łącznie z wizją zysków gospodarczych z paliw kopalnych i metali szlachetnych, których złoża znajdują się pod ziemią i pod dnem morza. Przyszłość jest nie do przewidzenia, a ja starałam się zrozumieć złożoność oczekiwań żywionych przez zamieszkujących te tereny ludzi, których literatura antropologiczna określa jako Inughuit, lecz którzy na własny użytek niespecjalnie dbają o tego rodzaju etykietki, świetnie wiedząc, kim są (obecnie bardziej wymieszani z innymi Grenlandczykami).

Niegdyś nazywano ich Eskimosami strefy polarnej. Tak nazwał ich duński (proto)etnograf Knud Rasmussen", który też, zakładając w 1910 roku swą placówkę handlową, zlokalizował mityczną Ultima Thule na północy mapy Grenlandii ${ }^{10}$. Wówczas było ich około 250, natomiast obecnie jest ich około 700 na rozległym obszarze, w którego centrum leży osada Qaanaaq. Mniej więcej dwie trzecie nadal żyje z myślistwa. Choć żyją na krańcach zamieszkiwanego świata, w oddaleniu od reszty Grenlandczyków, Inughuici są częścią społeczeństwa współczesnej Grenlandii i stoją wobec nowych wyzwań politycznych, środowiskowych i demograficznych. Równocześnie starają się nadal prowadzić życie łowców, wykorzystując odwieczne techniki, których jeśli chodzi o wykorzystanie naturalnych zasobów środowiska - nic nie jest w stanie przewyższyć.

Na podstawie własnych doświadczeń w Avanersuaq chciałabym w tym rozdziale omówić część procesu wytwarzania wiedzy w terenie w kategoriach

7 K. Hastrup The Nomadic Landscape: People in a Changing Arctic Environment, "Danish Journal of Geography" 2009 No. 109 (2), s. 181-190; K. Hastrup Arctic Hunters: Climate Variability and Social Mobility, w: The Question of Resilience. Social Responses to Climate Change, ed. by K. Hastrup, The Royal Danish Academy of Sciences and Letters, Copenhagen 2009; K. Hastrup Anticipation on Thin Ice: Diagrammatic Reasoning in the High Arctic, w: The Social Life of Climate Change Models: Anticipating Nature, ed. by K. Hastrup, M. Skrydstrup, Routledge, London 2013.

8 R. Gilberg Polar Eskimo, w: Handbook of the North American Indians, vol. 5: The Arctic, ed. by D. Damas, The Smithsonian Institution, Washington 1984.

9 K. Rasmussen The People of the Polar North: A Record, trans. and ed. by G. Herring, Kegan Paul, Trench, Trübner \& Co. Ltd., London 1908.

10 K. Hastrup Ultima Thule: Anthropology and the Call of the Unknown', ,Journal of the Royal Anthropological Institute" 2007 No. 13, s. 789-804. 
umiejętności. Tim Ingold kładzie nacisk na to, że umiejętności nie są po prostu technikami ciała, lecz zdolnością do działania i postrzegania, które rosną wraz z czynnym wchodzeniem w relacje z różnymi składnikami otoczenia" ${ }^{11}$. Będę starała się zbadać takie umiejętności jak wędrowanie, przewidywanie oraz określanie pory i czasu - umiejętności, które badacz terenowy zaczyna rozpoznawać, towarzysząc myśliwym poruszającym się w swym środowisku. W ostatniej części dodam jeszcze umiejętność porywania, która wydaje mi się kluczowa dla wytwarzania wiedzy, zarówno wśród łowców, jak i wśród antropologów. Wyjaśnienie umiejętności myśliwych w istotny sposób odzwierciedla też proces nabywania umiejętności (czy też zyskiwania wiedzy) przeze mnie jako antropolożkę w świecie łowców. Wyjaśnienie mojej drogi do tych umiejętności ilustruje też w bardziej ogólny sposób drogę do wiedzy antropologicznej, jako mocno opartej na równoczesności, by przywołać pojęcie wprowadzone przez Joahnnesa Fabiana (1983). Co istotne, ani współzamieszkiwanie, ani równoczesność nie oznaczają zlania się podmiotowości badacza terenowego i pierwotnych mieszkańców.

\section{Ruch: umiejętność wędrowania}

Kiedy postanowiłam wziąć udział w polowaniu na morsy i wyruszyłam na ciągniętych przez psy saniach przez zamarznięte morze na początku maja 2010 roku, szyblko znalazłam się pośród emocjonalnie nacechowanej topografii Północy, która budzi w podróżującym pewne uczucia i wrażenia ${ }^{12}$. Żadna budowla nie rozcinała rozległego horyzontu i nie było drzew, które mogłyby stanowić skalę umożliwiającą określenie odległości dzielącej nas od potężnych gór lodowych ani ich wielkości. Poruszanie się w terenie pokrytym śniegiem oznacza wplatanie wątku wędrówki w pozorny bezruch nieskończonego krajobrazu $^{13}$. Czasami psy i sanie pozostawiają na ziemi ślady, których nie da się z niczym pomylić; jednak w tej krainie śniegu i lodu są one ulotne.

Wyruszyliśmy w czasie, gdy zamarznięte morze pozwalało jeszcze na przejazd saniami do obfitujących w zwierzynę terenów łowieckich nad

11 T. Ingold The Perception of the Environment. Essays in Livelihood, Dwelling and Skill, Routledge, London 2000, S. 5.

K. Hastrup Emotional Topographies: The Sense of Place in the Far North, w: Emotions in the Field: The Psychology and Anthropology of Fieldwork Experience, ed. by J. Davies, D. Spencer, Stanford University Press, Stanford 2010. 
otwartym morzem. Dzięki temu można było polować na morsy i inne zwierzęta na skraju pokrywy lodowej, który - jak się okazało - znajdował się w odległości jakichś ośmiu godzin, czego z góry nie można było określić. Nie chodziło o niepewność co do odległości geograficznej: myśliwi byli tam wcześniej i wiedzieli, dokąd jadą. Nie mogli jednak wiedzieć, jak śnieg, lód i wiatr wpłyną na szybkość psów i na wybór szlaku. Świat przyrody, w którym uczestniczą, warunkuje ich ruch ${ }^{14}$.

Podczas wiosennych wypraw ku brzegowi pokrywy lodowej, gdzie morskie ssaki żerują i rozmnażają się w otwartym morzu, warunki ustala lód na powierzchni morza, który reaguje na prądy morskie, temperaturę i wiatr. Oczywiście myśliwi wiedzieli, że im bliżej do skraju zmarzliny, tym bardziej krucha pokrywa, której wytrzymałość nie wszędzie jest jednak taka sama. Powożenie zaprzęgiem wymagało więc szczególnej uważności, pozwalającej określić mocniejsze partie lodu od bardziej kruchych. Choć zamarznięte morze było terenem w pewnym sensie znanym, to było też zmiennym partnerem, jeśli chodzi o posuwanie się wyprawy łowieckiej do przodu, jak zwykle dzieje się w Arktyce ${ }^{15}$. Rozpoznanie drogi wymagało wyostrzonej „wrażliwości na znaki z otoczenia i większej zdolności, by na te znaki reagować odpowiednio i z wielką precyzją"16. Zwykle, jak mi powiedziano, o tej porze roku krawędź bywała o wiele dalej, ale w ciągu ostatnich dziesięciu lat morze rozmarza wcześniej i szybciej, a tereny łowieckie na skraju pokrywy lodowej, choć coraz mniej stabilne, zaczęły zbliżać się do Qaanaaq już wczesną wiosną. Mankamentem było jednak to, że dostęp do położonych dalej w głębi morza wysp, na których gniazdowały niezliczone ptaki przybywające z południa o tej porze roku, stawał się o wiele trudniejszy i ludzie tracili możliwość korzystania z tego bogactwa. Podróżowanie saniami oznaczało z jednej strony pogrążenie się w świecie lodu, wiatru i pogody, a z drugiej byłych i teraźniejszych możliwości polowania na innego. Sprawiało, że abstrakcyjny wymiar czasu znikał ze świadomości, podczas gdy starałam się z twarzy powożącego „przez ramię" - nie czytać jak Geertz" ${ }^{17}$ który dekodował kulturę jako tekst odczytać znaczenie niewielkich znaków topograficznych, które dostrzegałam,

14 Por. tamże, s. 133, 134.

15 A. Henshaw The Socio-cultural Dimensions of a Melting Environment in the Arctic, w: Anthropology and Climate Change, ed. by S.A. Crate, M. Nuttall, Left Coast Press, Walnut Creek 2009.

16 T. Ingold Footprints..., s. 134.

17 C. Geertz Interpretacje kultur: wybrane eseje, przeł. M. Piechaczek, Wydawnictwo UJ, Kraków 2005 , s. 500. 
siedząc w saniach za plecami myśliwego. Innymi słowy, poddałam się całkowicie doświadczeniu podróżowania; nie tyle poruszania się po powierzchni ziemi, ile w złożonym świecie tworzyw i ruchów, co umożliwiło pojawienie się zupełnie niespodziewanych pytań, których nigdy nie postawiłabym sobie, wychodząc od abstrakcji.

W Avanersuaq, gdzie myśliwi przez większość roku muszą polegać na psich zaprzęgach ślady sań tworzą linie wyraźnie widoczne na śniegu. Podobnie jak ślady stóp, są one tak ulotne, jak podłoże niepewne. „Ślady stóp istnieją więc w sposób ograniczony w czasie, a ich trwałość jest nierozerwalnie związana z dynamiką podłoża, którego są częścią; z cyklami organicznego wzrostu i rozpadu, pogody i pór roku"18. Jednak w tym konkretnym wypadku podróż na tereny łowieckie na skraju zamarzniętego morza oznaczała poruszanie się po szlaku, który był już odciśnięty w podłożu. Przez ostatnie dwa tygodnie myśliwi regularnie udawali się tam na trzy-, pięciodniowe wyprawy i szlak był wyraźnie widoczny, jeśli nie w formie prostej linii, to jako ścieżka klucząca i wijąca się zgodnie z ukształtowaniem terenu. Jej kapryśny przebieg stał się jeszcze bardziej widoczny na ostatnim (długim) etapie, gdy powożący musiał bardzo uważać, poruszając się nawet wyjeżdżoną wcześniej koleiną. W bardzo krótkim czasie mogły pojawić się nowe szczeliny, a lód stawał się coraz cieńszy w kolejnych miejscach. Nad niektórymi szczelinami duże sanie potrafiły bez trudu przejechać, natomiast inne trzeba było szybko zręcznie ominąć.

„Wędrowiec to istota, która podążając drogą życia negocjuje lub improwizuje swój szlak w miarę wędrówki. W tej wędrówce, podobnie jak w życiu, chodzi o to, by znaleźć drogę przez, a nie by dotrzeć w określone miejsce, czy do jakiegoś kresu [...] Podczas drogi dzieją się rzeczy, czynione są obserwacje, a życie się toczy"19. Odnosi się to także do drogi odbywanej po zamarzniętym morzu; zanim jednak rozwinę ten temat, chciałabym pokrótce opisać tryb podróżowania, który Ingold przeciwstawia wędrowaniu, o którym była mowa przed chwilą, czyli transport. Transport "przenosi pasażera po uprzednio przygotowanej płaskiej powierzchni. Ruch jest tutaj bardziej równoległym przesunięciem niż linearnym posuwaniem się naprzód i łączy punkty załadunku z punktem docelowym. Pasażerowi chodzi o to, by dosłownie dostać się z A do B, najlepiej w jak najkrótszym czasie" (tamże). Jak dodaje Ingold, transport w czystej postaci nie jest możliwy, ponieważ czas biegnie, a życie się toczy, także wówczas, gdy pasażerowie są w drodze.

18 T. Ingold Footprints..., s. 129. 
W moim doświadczeniu pasażerki sań z psim zaprzęgiem życie istotnie biegło, a droga nasycona była życiem i znaczeniami do tego stopnia, że godziny nie mijały jedna po drugiej, lecz splatały w kłąb intensywnego życia, niemierzalnego w metrach czy kilometrach. Biorąc pod uwagę stwierdzenie Ingolda, że nie ma czegoś takiego jak transport w stanie czystym, należałoby spodziewać się podobnego wniosku w odniesieniu do wędrówki w czystej postaci, lecz Ingold nie czyni takiej uwagi. W wypadku myśliwych tropiących zwierzynę z pewnością błędem byłoby zakładać, że nie chodzi im o dotarcie do konkretnego celu, nawet jeśli jego dokładna lokalizacja pozostaje niepewna. Celem wędrówki była krawędź lodowej pokrywy, ponieważ tam właśnie powstawało łowisko. Nie był to ostateczny ani geograficznie raz na zawsze ustalony kraniec, ponieważ krawędź mogła się przesunąć, a myśliwych czekały kolejne polowania, szlaki do celu i lód na wiodącej do niego drodze. Niemniej cel wędrówki był określony: była nim możliwość upolowania zwierzyny i zdobycia mięsa dla ludzi i psów. Myśliwi nie wyruszyliby bez tego celu; tutaj właśnie wędrówka przez jakiś obszar i ruch po linii splatają się ze sobą, a transport i wędrowanie łączą.

Dwa tryby poruszania się są sugestywnym i pomocnym narzędziem analizy, lecz nie należy ich traktować jako dających się jasno wyróżnić rzeczywistości empirycznych czy odrębnych sposobów istnienia. W złożonej sytuacji, jaką jest ruch w świecie, ściśle splatają się one ze sobą. Odnosi się to także do ruchu w szczególnych warunkach arktycznego krajobrazu, gdzie człowiek, poruszający się pośród żywiołów w poszukiwaniu nowych szans, splata w jeden wątek wędrówkę, przecieranie ścieżek i transport. Z analitycznego punktu widzenia jeden lub drugi termin może nam się wydać bardziej użyteczny w zależności od tego, na czym się w danej chwili skupiamy i jaki rodzaj wiedzy nas bardziej interesuje; jednak sugerowanie, że niektórzy ludzie, tacy jak myśliwi w Arktyce, wyruszają w drogę bez wyznaczonego celu, oznaczałoby, że nie traktuje się ich poważnie, nawet jeżeli ich ruchy widziane z zewnątrz wydają się niekonsekwentnym krążeniem to tu, to tam.

Podróż saniami w Arktyce potwierdza spostrzeżenie Ingolda, że ziemię postrzegamy kinestetycznie ${ }^{20}$. Kiedy mówimy, że grunt się wznosi czy też że powierzchnia lodu jest nierówna, odnosimy się do własnego doświadczenia poruszania się po nim; to doznania ciała determinują te sformułowania językowe - nasza świadomość mięśniowa. Oczywiście w rzeczywistości ziemia, po której chodzimy, składa się dla nas z płaszczyzn dalekich od regularności 
i niewiele mających wspólnego z naszym wyobrażeniem planety o równej powierzchni. Kilka lat temu, gdy po raz pierwszy jechałam zaprzężonymi w psy saniami, ku mojemu zaskoczeniu okazało się, że to samo dotyczy zamarzniętego morza. Na jego przeważającym obszarze powierzchnia wcale nie jest równa; być może dlatego, że zamarzło ponownie po tym, jak sztorm pogruchotał pierwszy lód, podczas gdy dryfujące kry odłupane z lodowców mogły stać się przyczyną kolejnych nierówności. Z daleka może wydawać się gładkie, lecz doświadczane od środka, podczas poruszania się po jego powierzchni, rzadko jest gładkie i nawet pasażer musi uważać, żeby stopami, które swobodnie zwisają po bokach sań, nie uderzać w sterczące kawały zamarzniętej kry. Odczucie nieregularności gruntu stopniowo staje się częścią świadomości mięśniowej.

W studium poświęconym wspinaczce Penelope Rossiter sugeruje nawet jeszcze bliższy związek między skalnym podłożem i człowiekiem, który je pokonuje. W trakcie wspinaczki skała, techniki wspinaczkowe i człowiek splatają się ze sobą w specyficzny sposób. Na skutek ich wymieszania „skały stają się ścianą wspinaczkową, a człowiek wspinaczem"21. To wzajemne ustanawianie się skały i człowieka podczas wspinaczki mieści się w szerszej koncepcji zanurzenia w świecie, który jest ożywiony. „Wiele osób podczas niezwykle krótkich chwil samego wspinania się, a także w poprzedzających wspinaczkę i następujących tuż po niej momentach zastanowienia i przypatrywania się skale ma poczucie, że nawiązuje dialog z jakąś ożywioną istotą"22. W tym świecie rozróżnienia ustępują poczuciu przepływu, które samo w sobie rozbija ustalone pojęcia ,ja”, czasu, umysłu i ciała ${ }^{23}$. Wspinacze wyrażali to, mówiąc o zmąceniu granic między podmiotem i przedmiotem, człowiekiem i skałą. „Wspinasz się tak samo na siebie, jak na skałę [...] jeśli niesie cię prąd, to wszystko jest nieruchome [...] i właściwie nie wiesz, czy to ty się poruszasz, czy skała"24. Można tu mówić o ontologii relacyjnej albo przynajmniej zastanawiać nad wzajemnym wpływem skały i człowieka: wydaje się, że albo płyną razem w tym samym nurcie, albo wcale się nie poruszają.

21 P. Rossiter On Humans, Nature, and Other Nonhumans, "Space and Culture" 2007 No. 10 (2), S. 293.

Tamże, s. 294.

M. Csikszentmihalyi Beyond Boredom and Anxiety, Jossey-Bass, San Francisco 1977, s. 96-97, za: P. Rossiter On Humans..., s. 294. 
Można to odnieść również do wędrowania w Arktyce, gdzie przemieszczanie się w polarnym krajobrazie prowadzi do wniosku, że „aby doszło do jakiejkolwiek interakcji między ludźmi i rzeczami, jej uczestnicy muszą być zanurzeni w przepływach otaczających mediów, podlegać działającym w nich siłom i ciśnieniu. Odcięcie od środowiska oznaczałoby ich śmierć"25. Ogólnie rzecz biorąc, chodzi o to, że wszystkie media, w które człowiek bywa zanurzany, są nie tyle przez niego postrzegane, co on sam postrzega się przez nie. Życia w Arktyce (i wszędzie indziej) nie można doświadczać poza żywiołami czy ponad nimi. To zaś każe myśleć o wzajemnym konstytuowaniu się ludzi i ich otoczenia - zwierząt, ziemi, powietrza, wody i lodu - podczas wędrówki. Świat, podczas drogi po lodzie osadzony w konkretnym sposobie poruszania się i poznawania, jest postrzegany w kategoriach substancji i sił, które otwierają lub zamykają konkretne szlaki wiodące do celu. Jeżeli więc poruszanie się przez jakiś obszar i poruszanie się po jakimś szlaku są w praktyce myśliwego nierozłączne, jak pisałam wcześniej, to odczuwanie tej wędrówki także zawiera w sobie różne tryby postrzegania: poczucie, że jest się niesionym przez prąd łączy się z rozumieniem potencjalnych celów wyprawy. I choć myśliwi bardzo bacznie obserwują lód, nigdy nie zapominają o wielkiej zwierzynie, która jest podstawą wyżywienia ludzi i psów.

Tropy wiodą też z powrotem do osady. Wyczuwa się to w kroku psów, które w pobliżu domu przyspieszają, podążając przeważnie po własnych śladach. Biegną szybciej, a rzemienie uprzęży są równo naprężone, co oznacza, że rzadziej się plączą i nie trzeba zatrzymywać zaprzęgu. Wyprawy łowieckie zawsze odbywają głównie mężczyźni, natomiast kobiety i dzieci zostają w domu. Dziś jest tak nawet jeszcze bardziej niż dawniej, gdyż życie społeczne koncentruje się wokół nowoczesnych udogodnień, takich jak sklep, szkoła, szpital i Internet. W związku z tym nomadyczny krajobraz skurczył się ${ }^{26}$, choć nadal można rozpoznać sieć szklaków potencjalnie łączących znaczące punkty w odpowiednim czasie i warunkach.

Podsumowując rozważania o wędrówce: dwa typy poruszania się wyróżnione przez Ingolda, wędrowanie i transport, okazały się dobrym narzędziem analitycznym do opisu wyprawy łowieckiej na dalekiej Północy. Jednak, choć pozwalają one wyjść poza dualistyczny podział na środowisko naturalne i społeczeństwo, to nie możemy zapominać, że ich podstawą także jest para przeciwstawnych pojęć, które empirycznie nie zawsze dają się od

25 T. Ingold Footprints..., s. 132.

26 K. Hastrup The Nomadic Landscape... 
siebie oddzielić i w praktyce mogą się ze sobą zlewać. Pozwalają nam jednak na nierównej powierzchni społecznych światów wyznaczyć pewne stałe punkty analityczne, tak ulotne, jak ślady na śniegu. Umiejętność wędrowania pozwala myśliwym na wyszukiwanie różnych celów, a w związku z tym daje im możliwość zakotwiczenia nawet w szybko zmieniającym się świecie. Z drugiej strony, etnograf podróżując wraz z nimi, ma szansę dostrzec trwałość tej społeczności, nawet jeśli osadzoną w niepewności. Co więcej, rodząca się świadomość mięśniowa wyjaśnia, dlaczego antropolodzy nieuchronnie działają na krawędzi natury ${ }^{27}$.

\section{Antycypacja: umiejętność przewidywania}

Wspomniane powyżej polowanie na morsy stało się w rzeczywistości polowaniem na fokowąsy, a w trakcie naszego obozowania na skraju zmarzliny nie pojawił się w zasięgu wzroku żaden mors. Fokowąsy zostały powitane z entuzjazmem i nikt się nie skarżył. Marzenie o większej zdobyczy wybrzmiało tylko w żartobliwej uwadze jednego z doświadczonych myśliwych, który wyruszając na pontonie zakotwiczonym przy krawędzi lodu, powiedział do mnie ze śmiechem: „Wrócę z białym niedźwiedziem i morsem”. Wrócił bez nich, ale nie narzekał. Wziął swoją część zdobycznych fokowąsów i miał nadzieję na więcej w drodze powrotnej, ponieważ na lodzie mogła się przecież trafić jakaś nerpa odpoczywająca obok przerębli oddechowej. Wiedział, że nigdy nie można określić z góry, co się upoluje, lecz zakładał, że w określonej porze roku, warunkach pogodowych i wietrze wyprawa jest warta zachodu. Element niepewności towarzyszący każdym łowom był wpisany w czynność przewidywania, która ma o wiele mniej losowy charakter W społecznościach łowieckich wyobraźnia dotycząca przyszłości zawsze opiera się na przewidywaniu pojawiających się na bieżąco szans. Hugh Brody na podstawie swych doświadczeń wśród polujących na renifery Nunavutów pisał tak:

Same łowy [...] muszą zarówno kwestionować przyzwyczajenia, jak i się na nich opierać: nie ma dwóch takich samych pór roku, a sezonowe wędrówki zwierząt nigdy nie są całkowicie przewidywalne. Myśliwi, podążając przetartym od dawna szlakiem, muszą umieć wykorzystywać nowe okazje i dostosowywać tempo i kierunek swych kroków do tropionych

27 K. Hastrup Nature: Anthropology on the Edge, w: Anthropology and Nature, ed. by K. Hastrup, Routledge, London 2013. 
zwierząt, od których zależy ich życie. W każdym momencie sezonowej wędrówki każdy musi ocenić i przetworzyć ogromną ilość informacji. Przyzwyczajenie i wzorzec mobilności tworzą ramy; działanie w ich obrębie stale się zmienia. ${ }^{\mathbf{2 8}}$

W wypadku polowania na - jak się okazało - fokowąsy, obozowisko zostało założone w odpowiednim miejscu i o odpowiedniej porze, na podstawie ogromnej ilości przetworzonej informacji, jeśli przyjąć kategorie Brody'ego. Udało nam się je założyć w bezpośrednim sąsiedztwie otwartego morza, choć przez parę godzin poprzedzających dotarcie w to miejsce jechaliśmy po dość cienkim lodzie, którego stan trzeba było bardzo uważnie śledzić. Nad saniami, które po przykryciu skórami reniferów izolującymi od chłodu bijącego od lodu, zamieniły się w legowiska, rozpięto zwykłe płócienne namioty. Leżąc w promieniach jaśniejącego o północy słońca i zapadając w sen, który niewiele miał wspólnego z nocnym odpoczynkiem, czuliśmy, jak lód pod nami się rusza, i słyszeliśmy, jak prądy przypływu powodują pojawianie się w nim drobnych spękań. Ostrzeżono mnie, żebym nie zasuwała śpiwora, ponieważ suwak mógłby zamarznąć, uniemożliwiając wyskoczenie w jednej chwili, gdyby pękanie lodu stało się groźniejsze.

Namiot, w którym spałam z czterema myśliwymi, dwadzieścia pięć kroków dzieliło od krawędzi zmarzliny, gdzie mogli oni wykorzystać szanse otwierające się tam przed nimi w sensie dosłownym. Kilka tygodni wcześniej przywieziono tu na saniach motorowych ponton z doczepionym silnikiem, który pozwalał rozpoznać to miejsce - tak długo, jak długo będzie ono istniało, biorąc pod uwagę zmienną naturę lodu. Za kilka tygodni przejazd po lodzie będzie już zbyt niebezpieczny, a obozowanie przy krawędzi zmarzliny niemożliwe ze względu na ryzyko oderwania się kry z człowiekiem czy sprzętem na skutek pękania lodowej pokrywy. Myśliwi z innej grupy, obozujący gdzie indziej, mieli się niemal otrzeć o taki wypadek, budząc się na pływającej krze; musieli szybko przenosić sprzęt i obozowisko z kry na krę, by w ciągu kilku minut znaleźć się „z powrotem” na twardym lodzie. Innymi słowy, istniał dość dobrze określony przedział czasu, w którym można było wykorzystać szansę, uzależniony od pory roku i żywiołów, a myśliwi z pewnością doskonale wiedzieli, co robią.

28 H. Brody Living Arctic. Hunters of the Canadian North, University of Washington Press, Seattle 1987, s. 89. 
Myśliwi potrafili też przewidywać pogodę na podstawie stanu nieba i wiatru. Kiedy w pewnej chwili zapytałam, czy napływające chmury i zmieniający się wiatr przyniosą śnieg, wszyscy natychmiast zgodnie stwierdzili, że nie. Ich wiedza opierała się na praktyce i doświadczeniu, co oznaczało, że nie odwoływali się do zeszłorocznej mądrości, lecz była to prognoza bieżąca, powstająca w trakcie naszej rozmowy., Świadoma uważność nie maleje wraz z nabywaniem praktyki, ani nie pogrąża się w mętnych głębiach nieświadomego automatyzmu, lecz wraz z coraz większą płynnością działania wzrasta jej skupienie i natężenie, podczas gdy zmysłowe zaangażowanie ciała w świat przeżywany coraz bardziej się rozszerza"29. Reakcja na praktyczne wyzwania nie polega nigdy tylko na sięgnięciu do zasobów wiedzy ucieleśnionej, do których można się zawsze odwołać w razie potrzeby; na zamarzniętym morzu trzeba umieć przewidywać, gdzie i kiedy szanse się otworzą i zamkną, czy to na skutek burz śnieżnych, czy pękania lodu, czy też działania innych żywiołów i sił. Sięga się więc do rozmaitych pośrednich wskazówek i wnikliwych obserwacji samego lodu ${ }^{30}$.

Zaskakujące, że o niektórych Inuitach z Kanady pisano, że nie mają poczucia przyszłości i generalnie niechętnie snują rozważania na jej temat: „twierdzenie, że posiada się jakąkolwiek wiedzę o przyszłości uznawane jest przez wielu Inuitów za próżność, a nawet arogancję; trudno się zatem dziwić, że nie chcieliby widzieć tego rodzaju dywagacji zapisanych w wywiadzie. Być może jednak ta inuicka filozofia odnosi się głównie do rozmów o zwierzętach"31. Rodzi się pytanie, dlaczego niechęć do przewidywania ruchów w świecie zwierząt została uznana za filozofię, a nie za wiedzę o zwierzętach, których przemieszczenia są faktycznie zawsze niepewne? Istnieją ogólnie rozumiane pory roku, z którymi skorelowane są migracje zwierząt, a niegdyś także różna morfologia społeczna ${ }^{32}$; najwyraźniej współcześni myśliwi w Avanersuaq także mają ich świadomość i starają się przewidywać możliwości. Kolejny sezon zawsze jest częścią przyszłości, o której myślą, a ich niechęć do

T. Ingold Footprints..., s. 136.

30 K. Hastrup Anticipating Nature:The Productive Uncertainty of Climate Models, w: The Social Life of Climate Change Models: Anticipating Nature, ed. K. Hastrup, M. Skrydstrup, Routledge, London 2013; zob. też I. Krupnik, C. Aporta, S. Gearhead, G.J. Laidler, L.K. Holm SIKU: Knowing Our Ice: Documenting Inuit Sea-Ice Knowledge and Use, Springer, New York 2010.

P. Bates Inuit and Scientific Philosophies About Planning, Prediction, and Uncertainty, "Arctic Anthropology" 2007 No. 44 (2), s. 93. łecznej, przeł. K. Pomian, w: tegoż Socjologia i antropologia, KR, Warszawa 2001 [1906], s. 415-512. 
formułowania prognoz nie ma nic wspólnego z filozoficznym podejściem, lecz wynika z praktycznej niepewności.

Podczas polowania człowiek musi być niezwykle czujny, by w każdej chwili błyskawicznie zareagować na możliwość schwytania zwierzyny; nie snuje więc rozważań nad przyszłoroczną zdobyczą podczas bieżących działań. A jednak zdaniem tego samego autora „inuickie filozofie czasu okazały się więc o wiele bardziej trwałe, niż można się spodziewać, mimo niewątpliwego zerwania ciągłości praktyk łowieckich na skutek osiadłego trybu życia. W związku z tym wielu Inuitów, jeśli to tylko możliwe, nadal posługuje się długoterminowym planowaniem i przewidywaniem wybiórczo i oszczęd-

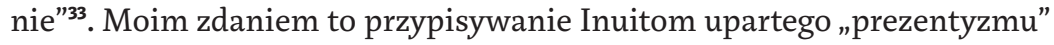
jest typowym przykładem allochronizmu, przeciw któremu Fabian próbował uodpornić antropologię przed ponad trzydziestu laty ${ }^{34}$.

Mankamentem trafnego pod wieloma innymi względami wkładu Batesa do etnografii Inuitów jest też implicite założona opozycja między wiedzą tradycyjną i naukową. Wiele uwagi poświęca on ich niechęci do przewidywania i rozmów na temat oczekiwań, jakie mają wobec przyszłości, oraz temu, że nie potrafią zrozumieć pojęcia zrównoważonego rozwoju. Jak wynika z jego analizy, niechęć Inuitów do rozmowy o przyszłych strategiach odstrzału wzmaga tradycyjna koncepcja społecznego zaangażowania obejmującego zwierzęta. „Wysiłki badaczy, by zachęcić Inuitów do rozważań o rozwiązaniach prowadzących do zrównoważonego rozwoju stad karibu w przyszłości są prawdopodobnie sprzeczne z inuicką filozofią, która mówi o tym, co można wiedzieć o zwierzętach, i o przyszłości, oraz najprawdopodobniej przejawem braku szacunku dla obu tych rzeczy. W związku z tym bywają wyjątkowo kłopotliwe dla inuickich rozmówców" ${ }^{35}$.

Choć postawa ta ma na pewnym poziomie wyrażać szacunek dla tubylczej wiedzy, na innym jest moim zdaniem bardzo niepokojąca: opiera się bowiem na założeniu głębokiej obcości wobec Zachodu i wobec nauki. Podwójnie negatywne zestawienie działa tak, że łowcy karibu (w tym konkretnym wypadku) znajdują się poza nowoczesnym światem. Jak przypomina Julie Cruikshank prowadząca badania w Ameryce Północnej, , skodyfikowana w rządowych sprawozdaniach informacja ujęta jako TWŚ [tradycyjna wiedza

33 P. Bates Inuit..., s. 92.

34 J. Fabian Time and The Other. How Anthropology Makes its Object, Columbia University Press, New York 1983. 
o środowisku - przyp. tłum.] zwykle reifikuje i wzmacnia zachodni dualizm natury i kultury, który lokalne narracje kwestionują przede wszystkim. Krajobraz, który czuje, zmieni postać, gdy pochłonięty przez ten system ulegnie przekształceniu w «ziemię i bogactwa naturalne»"36. Bycie gdzieś i przemieszczanie się z mieszkającymi tam ludźmi uczy nas właśnie tego: jak zmieniają się krajobrazy i jak w konkretnych sytuacjach pewne pytania dla nikogo nie mają sensu. Założenie a priori jakiejś tubylczości może w istocie uniemożliwić zrozumienie złożoności wiedzy i tego, co się na nią składa; oczywiście w Avanersuaq myśliwi „znają" swój świat ze wszelkich możliwych źródeł doświadczenia, miejsca i nagromadzonej wiedzy, z każdej strony i w każdym czasie, z obrazami satelitarnymi i innymi źródłami globalnej wiedzy włącznie.

Wyrażając w słowach szacunek dla wiedzy tubylczej, wspomniana postawa zbyt łatwo odwraca się też od wiedzy antropologicznej jako takiej. Problemem jest „utożsamienie tubylczości oraz istotyludzkiej z tym, co tradycyjne i lokalne, a także sposoby, za pomocą których takie ujęcie poszerza kolonialne formy wiedzy i praktyki" ${ }^{37}$. Nawet praktykowana w najlepszej wierze etnografia zapisująca „tubylczy głos" potencjalnie odmawia tym ludziom miejsca w globalnym porządku - klimatycznym, politycznym, moralnym i głęboko nowoczesnym, jeśli ten termin cokolwiek jeszcze znaczy. Znając ludzi z Avanersuaq, twierdzę, że ani ich świat, ani ich wiedza nie są bardziej tradycyjne czy lokalne od wiedzy i świata kogokolwiek innego, ani też nie są jednorodne. Ich świat jest umiejscowiony i wytwarza specyficzną „przestrzeń wiedzy”38, która sięga tak daleko, jak wymaga tego rozwiązanie konkretnej kwestii w danej chwili - czy chodzi o zachowanie zwierząt, relacje społeczne, globalne ocieplenie czy przyszłe możliwości nowych sposobów życia. Natężenie uwagi bardzo się zmienia w zależności od tematu i zainteresowania, a wiedza z pewnością nie odgrywa roli wyznacznika miejscowej filozofii czy ontologii ${ }^{39}$.

Podczas gdy znani mi myśliwi nie traktują długoterminowego planowania i przewidywania jako jedynego słusznego nastawienia wobec świata, i bywa, że

36 J. Cruikshank Glaciers andCclimate Change: Perspectives from Oral Tradition, "Arctic” 2001 No. 54 (4), s. 377-389.

37 E.S. Cameron Securing Indigenous Politics: A Critique of the Vulnerability and Adaptation Approach to the Human Dimensions of ClimateChange in the Canadian Arctic, "Global Environmental Change" 2012 No. 22, s. 111. tific and Indigenous Knowledge, Routledge, London 2003. 
także posługują się nim wybiórczo, to posiadają niezwykłą wiedzę o szansach, jakich świat dostarcza. Przy wyostrzonej uważności podczas polowania, gdy oczekuje się na odpowiedni moment, by zaatakować, koncentracja jest tak potrzebna właśnie ze względu na wpływ, jaki wynik łowów ma na przyszłość. Polowanie to przede wszystkim patrzenie w przód; wymaga łączenia aktualnych możliwości i przyszłych wydarzeń. Nie oznacza to jednak, że myśliwi mogą planować polowanie, kierując się przyszłymi potrzebami; to jednak spostrzeżenie natury praktycznej, a nie filozoficznej, i stosuje się prawdopodobnie do wszystkich myśliwych. Same dobre chęci nie wystarczą, by polowanie zakończyło się sukcesem. Przy dobrych prognozach myśliwi wyruszają z oczekiwaniem, że trafią na zwierzynę, lecz bez luksusu pewności, że to nastąpi. Ta cecha łączy ich z autorami prognoz dotyczących zmiany klimatycznejej.

Jak niezwykle celnie zauważył Mark Nuttall, „Inuici nie tylko przystosowali się do arktycznego środowiska, lecz także przewidzieli możliwości i warunki najlepszego w nim działania. W tradycyjnych społecznościach grenlandzkich myślistwo i rybołówstwo to nie tylko zdobywanie zaopatrzenia, lecz także przewidywanie ruchu fok, narwali, ryb i innych zwierząt łownych, czekanie na nie, nadzieja, że się pojawią, przemyślenia na ich temat oraz ich miejsce w wyobraźni, jak również oczekiwanie na powrót do domu i obawa, jaka mu towarzyszy"41.

Takie oczekiwanie jest doskonale wyczuwalne w społeczności Qaanaaq, nawet jeśli nic się specjalnie nie dzieje. Tutejszy rytm życia społecznego odzwierciedla różne sezony polowań, a większość ludzi stale wpatruje się w morze lub jego zamarzniętą powierzchnię, dopóki jest choć odrobina światła. Ja sama poczułam, że muszę kupić lornetkę, by podwoić zasięg ich spojrzenia i zacząć z własnego mieszkania rozpoznawać najodleglejsze oznaki ruchu czyli szansy. Bywało, że czasem ustawiałam się w szeregu „wypatrywaczy” i nie mogłam powstrzymać uśmiechu na myśl, że to patrzenie razem jest formą obserwacji uczestniczącej.

Z tego wszystkiego widać było jasno, w jak wielkim stopniu zarówno świat materialny, jak i świat zwierząt są sprawczymi elementami tkanki społecznej ${ }^{42}$. Świat arktyczny jest pełen sił, które wtłaczają się w mięśniową świa-

40 K. Hastrup Anticipating Nature...

41 M. Nuttall Anticipation, Climate Change, and Movement in Greenland, "Études/Inuit/Studies" 2010 No. 34 (1), s. 25.

42 Por. B. Latour Splatając na nowo to, co społeczne. Wprowadzenie do teorii aktora-sieci, przeł. K. Arbiszewski, A. Derra, Universitas, Kraków 2010. 
domość człowieka; zwierząt chodzących własnymi ścieżkami, na które ciało łowcy musi być wyczulone, oraz technik, za pomocą których bezpośrednio oddziałuje on na środowisko. Wszystko to razem „dostarcza możliwości wymyślania na nowo ja i przestrzeni, w których te ja działają i zamieszkują"43. Gatunki, od których w konkretnym regionie życie człowieka jest uzależnione, stają się częścią „społeczności-więcej-niż-ludzkiej”44.

Przypisywanie sprawczości zwierzętom i innym nie-ludziom można rozumieć przez odwołanie do Bruno Latoura i jego aktorów: „każda rzecz, która zmienia stan rzeczy, która wprowadza jakąś różnicę, jest aktorem [...] Stąd pytania, jakie zadajemy wobec każdego podmiotu, są następujące: Czy wprowadza on jakąś różnicę w przebieg działania jakiegoś innego podmiotu, czy nie?"45. W wypadku polowania bez większego problemu uznamy, że zwierzęta, zarówno zwierzyna łowna, jak i psy, wprowadzają różnicę w życiu myśliwych. Są jednak też inni ludzie oraz technologia i techniki: sanie, baty, piecyki, spodnie z niedźwiedziej skóry, harpuny, strzelby, kajaki, a także wspomnienia, dzieci do nakarmienia w domu itd. to wszystko również wprowadza różnicę i powinno być uznane za aktorów większego dramatu społecznego. Wszyscy ci aktorzy razem raczej umożliwiają konkretne działania, niż są po prostu ich przyczyną. Taka koncepcja sprawczości otwiera przestrzeń dla wprowadzania różnicy, sugerując, „że istnieją być może różne odcienie metafizyki między całkowitą sprawczością a zwykłym nieistnieniem: rzeczy mogą zgadzać się na coś, pozwalać, stwarzać warunki, zachęcać, zezwalać, sugerować, wpływać, blokować, umożliwiać, zabraniać i tak dalej, poza tym, że «determinować» działania ludzi oraz «stanowić ich tło»"46.

To sprawia, że wracamy do złożonego krajobrazu, na który składają się lód, zwierzęta, ludzie, światło, wiatr i morze. Powodzenie w łowach zależy zarówno od umiejscowionych umiejętności prognozowania, jak i od ogólnoludzkiej zdolności przewidywania; z pewnością jednak także od poruszeń nie-ludzkich sprawców, którzy przyczyniają się do zmienności świata. Oznacza to, że marzenia o podporządkowaniu natury człowiekowi pobudzone

43 P. Rossiter On Humans..., s. 303.

44 A. Tsing More-than-Human Sociality, w: Anthropology and Nature, ed. by K. Hastrup. Routledge, London 2013. 
przez oświeceniową naukę są i pozostaną „daremne zarówno ze względu na ograniczoną wyobraźnię, której są wyrazem, jak i na nieprzewidywalność żywej przyrody" ${ }^{\prime 4}$. Umiejętność prognozowania wyrabiana jest w toku długotrwałego uczestnictwa w świecie, w którym elastyczność i umiejętność chwytania okazji muszą dominować nad zdolnością do realizowania ustalonego planu, choćby powstał z powodów jak najbardziej godnych pochwały. Przede wszystkim dlatego, że „ruch jest elementem codzienności, zarówno w świecie społecznym grup inuickich, jak i w niespodziewanych zmianach tras sezonowych wędrówek białuch arktycznych czy w zachowaniu lodowców"48.

Dlatego właśnie, gdy chcemy zrozumieć, jak ludzie reagują na (spodziewaną) przyszłość i jak ją wytwarzają, prognozowanie okazuje się lepszym terminem niż przewidywanie i planowanie. Słuszne przewidywania muszą opierać się na jakiejś powtarzalności i niezmiennie zawodzą właśnie wtedy, gdy są najbardziej potrzebne - czyli wówczas, gdy powtarzalność zawodzi ${ }^{49}$. W świecie, w którym ludzcy i nie-ludzcy aktorzy są stale w ruchu i ciągle się przemieszczają a który dodatkowo wydaje się jeszcze bardziej nieprzewidywalny w związku ze zmianą klimatu, powtórzenie staje się coraz mniej prawdopodobne. Naukowe modele przyszłości klimatu oraz inne obecnie stosowane techniki przewidywania, będące w obiegu także na Grenlandii, mimo całej swej złożoności i wyrafinowania potrafią "przewidzieć” jedynie to, co już wiadome. Tego, co niewiadome, nigdy przewidzieć się nie da, jak uczą nas myśliwi z Arktyki. W istocie uświadomienie sobie tego stanowi część ich niezwykłych umiejętności, dzięki którym prognozują też potencjał swego otoczenia i szanse, jakie ono stwarza - to zaś pozwala im odpowiedzialnie działać w interesie przyszłości bez roszczenia sobie prawa do jej poznania. To zaś mogłoby stać się podstawą nowej wiedzy antropologicznej, która miałaby wpływ na ludzkie życie.

\section{Działanie: umiejętność określenia dobrej pory}

Nabywanie umiejętności to nie tylko kwestia nauczenia się pewnych technik i prognozowania szans, które mogą się pojawić w złożonej sieci aktorów;

P. Rossiter On Humans..., s. 302. 
trzeba też potrafić zinterpretować znaczenie różnych aktorów względem siebie nawzajem oraz określić porę własnego działania. Naprawdę wiedzieć to być zdolnym do działania w teraźniejszości, a nie tylko reagować na to, co już się stało; reagować na wizję fabuły i odpowiednio oceniać własne miejsce w całym dramacie ${ }^{50}$. Działanie nigdy nie jest po prostu zjawiskiem „teraźniejszości”, lecz także częścią przewidywanego nurtu płynącego ku „przyszłości"51. Natężenie działania i jego płynność zakładają dobre wyczucie bieżącej czasoprzestrzeni dramatu; myśliwi nie siedzą pogrążeni w analizie swych ucieleśnionych wspomnień, by znaleźć odpowiedź na pytanie, czy w danej chwili działać, czy też nie. Świadomość mięśniowa sprawia, że przewidywanie zawiera się w samym ataku w odpowiedniej chwili. W tej części chciałabym postawić tezę, że określenie dobrej pory jest praktycznym zwieńczeniem ludzkiej zdolności przewidywania.

Jest dobry czas na polowanie i czas zły, istnieje zmienność zależna od pory roku; nawet podczas samych łowów są chwile wielkiego skupienia i czas pozornej bezczynności. Jednak podczas wyprawy łowieckiej nie ma czasu, w którym nic się nie dzieje; nawet podczas dość długich okresów oczekiwania uwaga myśliwych jest wyostrzona. Są zanurzeni w czasie, a ich zadanie polega na wybraniu odpowiedniej pory. Pod słońcem jaśniejącym o północy zegar jest być może nieistotny, lecz inne rytmy i oznaki domagają się uwagi: przypływ, prądy morskie, wiatry, głodne psy, naprawa sprzętu - jednak żadna z tych rzeczy nie odwraca uwagi skupionej (w tym konkretnym wypadku) na wodzie, od której może nadejść spełnienie pragnień. Kiedy jest dobry moment, by wyruszyć? To pytanie wisiało w powietrzu, a czas - tak jak wiatr i powietrze - stał się medium, w którym zanurzone były inne żywioły, oceniane z perspektywy odpowiedniej pory.

W środowisku naturalnym Arktyki ludzie wykształcili wyjątkową wrażliwość w postrzeganiu oznak przydatnych w ocenie obietnicy chwili:

Czasami brak linii horyzontu. która oddziela niebo od ziemi, a sceneria jest całkowicie niezróżnicowana dla wzroku. Jednak Eskimos potrafi podróżować sto i więcej mil przez tę pustkę. Kieruje się w mniejszym stopniu wskazówkami wizualnymi, a w większym akustycznymi, węchowymi

50 K. Hastrup Performing the World: Agency, Anticipation and Creativity, w: Creativity and Cultural Improvisation, ed. by E. Hallam, T. Ingold, Berg, Oxford 2007, s. 199.

51 W. James, D. Mills Introduction, w: The Qualities of Time: Anthropological Approaches, ed. by W. James, D. Mills, Berg, Oxford 2005, s. 2. 
i dotykowymi. Prowadzi go wyczucie kierunku, zapach wiatru, śnieg i lód, które czuje pod stopami. ${ }^{52}$

Podczas gdy dla Tuana jest oczywiste, że niezróżnicowane otoczenie to pustka, umiejętności arktycznych myśliwych mówią im coś zupełnie innego. Dźwięki mogą informować o zwierzynie, a koleiny w śniegu wskazywać obecność innych ludzi w pobliżu; ci zaś mogą stanowić źródło aktualnych informacji o potencjalnym łupie. Świeże tropy na śniegu mogą doprowadzić do zwierzyny myśliwego, który je dostrzeże. By uchwycić odpowiedni moment, potrzeba poprawnej interpretacji koordynat i wzajemnego wzmacniania się (lub znoszenia) aktorów. Tam, gdzie przetrwanie zależy od umiejętności określenia odpowiedniej pory, w teraźniejszości tłoczy się tyle przyszłości, że nieomal wydaje się jej za dużo.

Dla wielu naukowców (a nawet dla niektórych antropologów) łowcy-zbieracze reprezentują dziewiczy stan człowieka pierwotnego poza czasem: niezdolni, by planować i oszczędzać na przyszłość, skłonni do natychmiastowej konsumpcji53. Oczywiście to pomyłka: nawet tam, gdzie czas nie jest pieniądzem w znaczeniu społeczeństwa przemysłowego, odpowiednią porę trzeba zawsze dobrze określić, odnoszące się do czasu wskazówki są przedmiotem przenikliwej uwagi. Na przykład wyruszenie kajakiem na wyprawę łowiecką na narwala nie tylko oznacza pościg, lecz także przewidywanie przyszłej pozycji zwierzęcia, przy uwzględnieniu jego szybkości oraz prądów morskich, zestawianych z potencjalną prędkością kajaka i kierunkiem, w którym płynie. Myśliwy musi przewidzieć miejsce spotkania z wielorybem i celnie rzucić harpunem. To z kolei wymaga wnikliwej obserwacji słońca, gdyż cień myśliwego nie może padać w stronę zwierzęcia, ponieważ narwal zmieni wówczas kurs. Interpretacja tak skomplikowanych działań jako bezczasowości nie ma sensu.

Sugerują one raczej bardzo złożone poczucie czasu, które można uznać za kolejne wyjaśnienie niechęci do formułowania przewidywań. Podobnie jak cytowany już Bates, doświadczyłam sytuacji, w których ludzie uciekają od odpowiedzi na stawiane wprost pytania o przyszłość. Mówią, że nie wiedzą. Oczywiście, nikt przecież nie zna przyszłości. Jednak podczas codziennego przebywania z nimi i uważnego wsłuchiwania się w uwagi dotyczące ptaków,

\footnotetext{
52 Y. Tuan Topophilia: A Study of Environmental Perception, Attitudes and Values, Columbia University Press, New York 1990, s. 77. 
potoków biorących początek z lodowców, nowych gatunków ryb, które pojawiły się w wodach Północy, problemów z oświatą, kurczących się szans dla kobiet i młodych ludzi ze względu na coraz bardziej ograniczone możliwości polowań itd., udaje się złożyć obraz ich troski o przyszłość. Mimo tych niepokojów starają się robić to, co potrafią, podejmując w zależności od pory decyzję, by wyruszyć na łowy lub by zostać w domu. Wpisują się w to także ich ciągle toczące się narady, czy przenieść się na południe i kiedy lub czy może przynajmniej wysłać tam dzieci do szkoły. Przyszłość jest implikowana przez teraźniejsze działania.

Podczas obozowania z myśliwymi na krawędzi zmarzliny doświadczyłam, jak z pozoru pusty czas oczekiwania pełen był czasów przeszłych i przyszłych: przerabianie bata na psy, ostrzenie narzędzi, karmienie psów, krojenie fok wyciągniętych na brzeg, a nawet pogawędki nad kolejnym kubkiem herbaty w lodowatym zimnie - wszystko to mocno osadzało teraźniejszość w minionych działaniach i przyszłych możliwościach. Z zewnątrz wyglądało być może, że myśliwi mają czasu co niemiara; od środka czuło się, że zanurzeni w nurcie czasu muszą być stale w gotowości i nie mogą przegapić odpowiedniej chwili. Sprzyjającą porę koniecznie trzeba dobrze określić, ponieważ kolejna okazja może się już nie zdarzyć. Właśnie dlatego żyją tak intensywnie zanurzeni w czasie, że nawet antropolodzy mogą nie zauważyć, do jakiego stopnia ich życie jest nim przesiąknięte. Chwytanie okazji, gdy ta się pojawi, i życie w niepewności, która zmusza do przedkładania odpowiedniej chwili nad długoterminowe plany, oraz stawianie świadomości mięśniowej nad deklaracjami, gdy chodzi o podstawę działania - wszystko to sprawia, że dobre określenie pory decyduje, czy będzie to czas uczty, czy czas głodówki.

W kontekście aktualnych zmian klimatu umiejętność określenia dobrej pory staje się jeszcze bardziej na czasie, gdyż nowe okazje, które mogą się pojawić, trzeba łapać, dopóki jeszcze można: cały czas bowiem inne znikają. Generalnie rzecz ujmując, zmiany klimatu rozumiane są w Grenlandii w ramach ogólnego poczucia nieustannego wytwarzania świata, pojawiających się środowisk i afordancji ${ }^{54}$. To element życia w niepewności, która sprawia, że na pytanie wprost odmawia się wygłaszania przepowiedni dotyczących przyszłości. Zwracają one też uwagę, że przewidywanie rozumiane jest ,jako

54 M. Nuttall Living in a World of Movement: Human Resilience toEnvironmental Instability in Greenland, w: Anthropology and Climate Change, ed. by S. Crate, M. Nuttall, Left Coast Press, Walnut Creek 2009, s. 299. 
forma wiedzy, jako ontologia, widzenie naprzód i patrzenie w głąb, jako sprzęgnięcie ze światem, zorientowanie w nim, samorealizacja, jako rozumienie potencjału"55.

Wszystkie formy wiedzy są umiejscowione i dogłębnie empiryczne; o jaką by ogólną wiedzę chodziło, zawsze opiera się ona na bliskiej obserwacji rzeczywistości: nawet do komputerowych modeli klimatu wprowadza się (selektywnie wybrane) obserwacje i dane z realnego świata, czy to dotyczące atmosfery, czy pokrywy lodowej ${ }^{56}$. Podobnie jak antropolodzy, przyrodnicy muszą zaakceptować niepewność i za niezwykle użyteczną dla przewidywania przyszłości uważają dogłębną wiedzę o pokrywie lodowej - tym archiwum dawnych klimatów ${ }^{57}$. Oznacza to, że kiedy dochodzi do potężnych załamań środowiska, jak dzieje się obecnie w Arktyce, zarówno myśliwi, jak i naukowcy muszą żyć, uwzględniając pewien stopień niepewności, który sprawia, że odpowiedzialne działanie coraz bardziej zależy do dobrego określenia odpowiedniej pory na podstawie wniosków płynących z przeszłych i teraźniejszych wskazówek.

Podstawową nauką z tych rozważań o prognozowaniu jest to, że z perspektywy udanego polowania znaczenie ma nie czas jako taki, lecz określenie odpowiedniej pory, które opiera się zarówno na ludzkiej zdolności przewidywania, jak i wyczulonej umiejętności interpretacji. Odnosi się to także do antropologicznego polowania na wiedzę: także w tym wypadku są dobre i złe momenty, by stawiać konkretne pytania, oraz wybitnie nieproduktywne sposoby badania.

\section{Wiedza: umiejętność abdukcji}

Im człowiek jest bardziej kompetentny, tym lepiej potrafi zareagować precyzyjnie na każdą sytuację. Jak ujmuje to Ingold ${ }^{58}$, nie chodzi o to, ile się wie, lecz jak dobrze się wie, a ktoś, kto wie dobrze, potrafi odróżniać. Dalej Ingold stwierdza, że Sherlock Holmes był niezwykle kompetentny właśnie w tym znaczeniu. Był mistrzem abdukcji, a jego umiejętności wyrażały się „w tym, że

\footnotetext{
55 M. Nuttall Anticipation..., s. 33.

K. Hastrup Anticipating Nature...

P. Ditlevsen Predictability in Question: On Climate Modelling inPphysics, w: The Social Life of Climate Change Models: Anticipating Nature, ed. by K. Hastrup, M. Skrydstrup, Routledge, London 2013. 
potrafił wyciągnąć całą serię wniosków o przeszłych wydarzeniach z oględzin jednego śladu"59. Moglibyśmy więc uznać, że ten sam rodzaj umiejętności posiada tropiący zwierzynę myśliwy. Abdukcja to pojęcie z zakresu semiotyki, wprowadzone przez C.S. Pierce'a dla określenia twórczego procesu dochodzenia do najlepszego możliwego wyjaśnienia. Za Alfredem Gellem można by rozszerzyć jego zakres poza semiotykę i zastosować jako bardziej ogólną zasadę wnioskowania: „Abdukcja obejmuje szarą strefę, w której wnioskowanie semiotyczne (o znaczeniach na podstawie znaków) łączy się w jedno $\mathrm{z}$ wnioskami hipotetycznymi o charakterze pozasemiotycznym (lub niekonwencjonalnie semiotycznym), tak jak w wypadku Keplera, który wychodząc od pozornego ruchu Marsa na nocnym niebie, doszedł do wniosku, że planeta porusza się po torze eliptycznym ${ }^{60}$. Zatem wyjaśnienie, ku któremu prowadzi nas abdukcja, jest możliwe, acz niekonkluzywne, wywnioskowane z obserwacji, lecz z niej dowodnie nie wywiedzione. Działanie antropologa odzwierciedla taki właśnie proces: wytężona uwaga, z jaką obserwowani są ludzie, tropy, psi zaprzęg i sanie, pogoda, opowieści, tworzy solidne podstawy do wyciągania wniosków na temat racjonalnych wyjaśnień konkretnych działań.

Wiedzieć tyle, żeby umieć określić - to właśnie kluczowa cecha umiejętności abdukcji arktycznych myśliwych. Nie oznacza to bynajmniej, że wygłaszają oni na ten temat wykłady dla szerokiej publiczności czy piszą długie traktaty. Wędrówka w bezkresnym krajobrazie, przewidywanie potencjalnych szans, określanie czasu łowów - to umiejętności, które można by wspólnie ująć jako „wiedzieć tyle, by umieć określić”. W świecie myśliwych umiejętności i wiedza to dwie strony tej samej monety ${ }^{61}$; i tak też muszą one działać dla antropologa, który z myśliwymi przestaje. U podstaw umiejętności wędrowania, przewidywania i określania dobrej pory leży uważność, z jaką myśliwi podchodzą do otaczającego ich świata.

Faktura i forma arktycznych krajobrazów to niezwykła mieszanka pustki i masywnej twardości, grup ludzkich żyjących w ogromnym rozproszeniu i wielkich odległościach od siebie oraz bardzo bliskich więzi społecznych, w których bliskość wynika z bycia razem w konkretnych warunkach, czynnościach i sytuacjach. W tym sensie nawet samotna wędrówka w arktycznym krajobrazie jest praktyką społeczną: myśliwy, który tak jak inni wpisuje

59 Tamże.

60 A. Gell Art and Agency: An Anthropological Theory, Clarendon Press, Oxford 1998, s. 14.

61 Por. T. Ingold The Perception..., s. 55-56. 
się w topografię, nigdy nie jest poza zespołem więzi łączących go zarówno z ludźmi, jak i z przemierzaną krainą. Wiedza wędrowca „nie opiera się na klasyfikacji, lecz ma charakter opowieści; nie jest totalizująca i synoptyczna, ale otwarta i eksploracyjna"62. Eksploracja to działanie zbiorowe, podobnie jak antropologia, którą uprawia się, nie tylko rozmawiając z ludźmi w terenie, lecz także wchodząc w dialog z wcześniejszymi etnografiami i refleksją teoretyczną.

$\mathrm{Na}$ Północy opowieści zbiera się także, będąc w drodze. Oddaliliśmy się już znacznie w stronę terenów łowieckich, gdy wyprzedziły nas jakieś sanie; jeszcze inne nas dogoniły; i za każdym razem, gdy zbliżały się do siebie dwie lub więcej par sań, jadący przodem zwalniał, a kiedy zaprzęgi się zrównywały, zatrzymywano je i robiono przerwę. Można wtedy było rozplątać psom uprząż i napić się herbaty z termosu, ale najważniejsze były zawsze informacje - niekoniecznie wiadomości ze świata, lecz informacje o stanie lodu i możliwościach polowania. W osadzie ludzie także starali się być na bieżąco i myśliwi wyruszający na łowy lub powracający ze zdobyczą byli stale przedmiotem zainteresowania. Cała rodzina i przyjaciele bacznie obserwowali pokryty lodem fiord przez lornetkę i wychodzili na plażę, by powitać powracających myśliwych i usłyszeć najświeższe nowiny; szybko zaczęłam robić to samo. Bywa zresztą, że wracający myśliwi dzwonią, gdy znajdą się już w zasięgu sygnału, żeby oczekujący wyszli im na spotkanie. Wiedzą (i mięsem) należy się podzielić z innymi mieszkańcami osady.

Myśliwi nieczęsto wymieniają się ogólnymi opiniami na temat zmniejszającego się pogłowia tego czy innego gatunku zwierząt. Przeważnie dzielą się praktyczną wiedzą o tym, na ile można liczyć na zdobycz. Opowieści mają spersonalizowany charakter i formę anegdot, opisują sukcesy i porażki, szczeliny w lodzie, które udało się ominąć itd. Anegdoty uświadamiają, że nie można całego doświadczenia zredukować do wiedzy w naukowym rozumieniu. Rozległe obszary doświadczenia pozostają z boku, nie uczestniczą bezpośrednio w tworzeniu totalizującej wiedzy, lecz mimo to stanowią źródło znajomości zmieniającego się stanu fauny i jego rozumienia.

Nabywanie umiejętności przez arktycznych myśliwych współbrzmi z wytwarzaniem wiedzy antropologicznej w Arktyce: oni i my podzielamy konkretną, umiejscowioną znajomość przestrzeni, rozumiejąc ją, jak pisał David Turnbull, jako „interaktywny, przygodny asamblaż przestrzeni i wiedzy, 
wytwarzany w trakcie społecznych działań i przez nie podtrzymywany" ${ }^{\text {"3 }}$. Podczas badań i wędrówki z ludźmi antropolog jest z nimi współumiejscowiony, równocześnie gromadzi wiedzę i przestrzeń podczas wspólnych działań. Choć Ingold twierdzi, że antropolog zanurzony w jakimś środowisku wspólnych działań „uczy się widzieć rzeczy (lub słyszeć je czy wyczuwać dotykiem) w taki sposób, jak robią to jego nauczyciele i towarzysze" ${ }^{\text {"64 }}$,ja mam inne zdanie. Nigdy nie potrafimy w pełni poznać sposobu widzenia świata przez innych ludzi; poza tym inni wcale nie widzą go na jeden sposób - wiemy to także z relacji z najbliższymi sobie ludźmi we własnym domu. Jednak gdy jesteśmy współ-umiejscowieni, możemy starać się zrozumieć, jak powstają w trakcie społecznych działań konkretne asamblaże wiedzy i w jaki sposób konkretne problemy błyskawicznie skupiają na sobie uwagę.

Żeby wiedza antropologiczna była zarówno antropologiczna, jak i była wiedzą, nie wystarczy twierdzić, że zrozumiało się „ich sposób widzenia” świata, a stwierdzenie tego rodzaju trudno jest obronić. Moim zdaniem antropologia to przykład umiejętności abdukcji, której celem jest konfigurowanie świata - jednak nie przez naśladowanie świata myśliwych (czy kogokolwiek innego), lecz dzięki tropieniu istotnych związków między znaczącymi aktorami, ludzkimi i nie-ludzkimi, w miarę, jak pojawiają się one w toku realnego życia. Aktorzy (w znaczeniu Latourowskim) przyjmują w praktyce konkretne kształty i formy; przybierają postać w procesie uświatowiania ${ }^{65}$. Postać nie jest przypadkowa; gdzieś mogą to być morsy, gdzie indziej traktory, mnisi, winne grona, wielbłądy, krzyże, uchodźcy, ciemności, rzeki, czarownice, północne wiatry czy cokolwiek innego. Rzeczy, które mogą mieć znaczenie, jest nieskończenie wiele; jednak pozostawiają one ślad tylko w konkretnym miejscu i w określonych punktach w czasie, w łączności z innymi rzeczami. Proces uświatowiania nie ma granic, ale nie wszystko ma sens w każdym czasie. Antropologia stara się wyciągać wnioski dotyczące „jak” i „dlaczego” tych postaci, zarówno konkretnie i szczegółowo, jak i w kategoriach ogólnych.

Żeby wiedza antropologiczna pozostawała wierna światu, i równocześnie wykraczała jednak poza zwykły opis, jej orędownicy muszą mieć dostęp do postaci, które mają znaczenie w konkretnym społecznym asamblażu wiedzy

64 T. Ingold Anthropology is not Ethnography, "Proceedings of the British Academy” 2008 No. 154, s. 82 .

65 A. Tsing Worlding the Matsutake Diaspora: Or, Can Actor-Network Theory Experiment With Holism?, w: Experiments in Holism, ed. by T. Otto, N. Bubandt, Blackwell, Oxford 2010. 
i przestrzeni. Pewne skojarzenia i aktorzy znaczą więcej niż inni i w nieskończonej przestrzeni ludzkiej wyobraźni tylko niektóre elementy mają sens w każdym miejscu czy w odniesieniu do każdego obiektu. I nie można tego rozstrzygnąć jedynie na podstawie wywiadów i rozmów, lecz muszą się one ucieleśnić w życiu, jako coś, co jest przeżywane. Czasami poruszamy się po wybojach i zdarza się, że antropolog doświadcza tego, co czerpiąc inspirację od Deleuze'a i Guattariego ${ }^{66}$, określiłam jako "surowy moment” etnograficznego doświadczenia. To chwila zauważalnej rozłączności między kodem i terytorium - czy też między wiedzą i przestrzenią - która z perspektywy percepcji ma dla antropologa potencjał edukacyjny. „Percepcja nie dostarcza mi prawdy, jak geometria, lecz obecności" ${ }^{\prime \prime}$. Zatem surowy moment nie jest chwilą dezorientacji w terenie, ,to chwile, w których umiejscowienie $w$ obszarze terenu badań rzutuje na podmiotowość i umożliwia niezapośredniczoną percepcję czegoś, czego nie można nazwać, lecz co przejawia się jako obecność" ${ }^{68}$. Już w trakcie swego trwania taka chwila jawi się jako posiadająca niezwykle ważne, choć jeszcze niezgłębione, znaczenie.

Takie momenty etnograficzne są oczywiście osadzone w większym projekcie antropologicznym, jakim jest współdzielenie świata i myślenie $z$ nim raczej - czy też z jakąś jego częścią - niż o nim. Praktykując umiejętności abdukcji pośród świata o nieograniczonych afordancjach, jeśli chodzi o ludzi i praktyczną mądrość, antropolodzy nieustannie przecierają nowe szlaki myślenia o ludzkiej kondycji z bardziej ogólnej perspektywy. Nabywając nowej świadomości mięśniowej, uczą się, że percepcja jest zestrojona z konkretną przestrzenią wiedzy, oraz dowiadują, jak powstają powiązania i w jaki sposób światy ulegają rekonfiguracji w praktyce. Tego rodzaju wiedzy antropologicznej, która jest analogiczna do świata w każdej jego części, udaje się dotrzeć dość daleko, zarówno jeśli chodzi o wyjaśnienie kwestii jedności życia społecznego, jak i jego zróżnicowania.

Kładzie też nacisk na subiektywny wgląd uzyskany przez etnografów w terenie, który zasadza się na obecności innych ludzi oraz założeniu „znajomości wspólnego świata obiektów we współdzielonym czasie i przestrzeni”, by użyć sformułowania Donalda Davidsona. Jak tenże stwierdza dalej, „nabywanie

G. Deleuze, F. Guattari Tysiąc plateau. Kapitalizm ischizofrenia, red. J. Bednarek, Fundacja Nowej Kultury Bęc Zmiana, Warszawa 2015.

67 M. Merleau-Ponty The Primacy of Perception, ed. by J.M. Edie, Northwestern University Press, Evanston, IL 1964, S. 14.

68 K. Hastrup Emotional Topographies..., s. 206. 
wiedzy nie opiera się na postępie od subiektywności do obiektywności. Wyłania się jako całość i od początku ma charakter holistyczny i interpersonalny" ${ }^{19}$.Za pomocą pojęcia świadomości mięśniowej chciałam podkreślić, że taka holistyczna wiedza opiera się w sposób trwały i nieunikniony na współzamieszkiwaniu, i obejmuje poczucie miejsca oraz poruszania się z ludźmi i wśród ludzi.

\section{Podziękowania:}

Dziękuję Duńskiej Radzie Badań Kultury i Komunikacji za wsparcie pierwszych badań terenowych w Grenlandii oraz Europejskiej Radzie do spraw Badań Naukowych za przyznanie grantu, który pozwolił mi na ich kontynuację w ramach szerszego projektu o nazwie „Waterworlds”, Centrum Antropologicznych Badań nad Klimatem na Uniwersytecie Kopenhaskim. Podziękowania za użyteczne komentarze zechcą przyjąć: Frida Hastrup, Helena Patzer, Tomasz Rakowski, Bob White i Kiven Strom.

Przełożyła Ewa Klekot

69 D. Davidson Problems of Rationality, Clarendon Press, Oxford 2004, s. 18. 


\section{Abstract}

\section{Kirsten Hastrup}

UNIVERSITY OF COPENHAGEN

Muscular Consciousness: Knowledge-Making in an Arctic Environment

Hastrup discusses the process of knowledge-making in anthropology, as based on fieldwork, yet not reducible to this. She organizes her argument in terms of skills, a concept that is owed to Ingold (2000) who stresses that skills are not simply techniques of the body, but capabilities of action and perception, growing through an active engagement with the constituents of the surroundings. The skills identified here, and by which the hunters relate to their world, are the skills of wayfaring, of forecasting and of timing - skills that the fieldworker identifies when going along with the hunters. In the concluding section, Hastrup addresses the skill of abduction, which she see as the core of knowledge making, among hunters as well as anthropologists.

\section{Keywords}

anthropology, fieldwork, skill, body, perception, abduction, hunting 